\title{
Relationship of mortality with neutrophil/lymphocyte ratio, platelet/lymphocyte ratio, and mean platelet volume in patients undergoing acute abdominal surgery
}

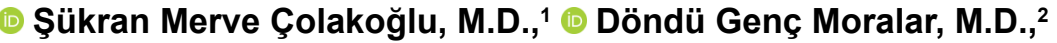 \\ (1) Büşra Tok Çekmecelioğlu, M.D., ${ }^{3}$ 무 Gülsüm Oya Hergünsel, M.D. ${ }^{2}$
}

\begin{abstract}
${ }^{1}$ Department of Anesthesia and Reanimation,University of Health Sciences, Gaziosmanpaşa Taksim Training and Research Hospital, İstanbul-Turkey

${ }^{2}$ Department of Anesthesia and Reanimation, University of Health Sciences, Bakırköy Dr. Sadi Konuk Training and Research Hospital, İstanbul-Turkey

${ }^{3}$ Department of Anesthesia and Reanimation, University of Health Sciences, Sultan Abdulhamid Han Training and Research Hospital, İstanbul-Turkey
\end{abstract}

\begin{abstract}
BACKGROUND: Acute abdominal surgery has a high rate of mortality and morbidity, and intensive care is often needed in the postoperative period. In intensive care units, various scoring systems are used to determine prognosis and mortality but are not sufficient to predict mortality and prognosis. For this purpose, easily applicable, effective methods are being investigated. In this study, we aimed to investigate the relationship between mortality and blood parameters, such as neutrophil-lymphocyte ratio (NLR), platelet-lymphocyte ratio (PLR), and mean platelet volume (MPV), in patients undergoing acute abdominal surgery.
\end{abstract}

METHODS: This study included a total of 249 patients who underwent acute abdominal surgery. The patients were divided into two groups as survivors $(n=126)$ and non-survivors $(n=123)$. The patient data were retrospectively analysed. The NLR, PLR, and MPV values were compared between the groups. Data including age, sex, Acute Physiology and Chronic Health Evaluation II-IV scores (APACHEII-IV), Sequential Organ Failure Assessment scores (SOFA), Glasgow Coma Scale were assessed.

RESULTS: The mortality rate was $49.4 \%$ in our study. There was no statistically significant difference in the NLR and PLR values between the groups. However, MPV was significantly higher in the non-survivors group $(p<0.004)$.

CONCLUSION: Our study results showed that MPV values were significantly higher in the non-survivors following acute abdominal surgery, and NLR and PLR were not associated with mortality.

Keywords: Acute abdomen; intensive care unit; mean platelet volume; mortality; neutrophil/lymphocyte ratio; platelet/lymphocyte ratio.

\section{INTRODUCTION}

Non-traumatic pathological events, which suddenly involve in any of the intra-abdominal organs and cause serious life-threatening conditions, are classified under the title of an acute abdomen. ${ }^{[I]}$ Patients undergoing acute abdominal surgery often need intensive care in the postoperative period. In recent years, studies have increasingly addressed the optimal use of the intensive care resources and correct prediction of the outcome in critically ill patients. Although the Acute Physiology and Chronic Health Evaluation (APACHE) II-IV and Sequential Organ Failure Assessment (SOFA) scores are widely used in the prediction of the mortality and morbidity, yielding satisfactory results, studies for the more easy-to-use tools to identify the risk of mortality and organ dysfunction are still going on. ${ }^{[2-4]}$

Cite this article as: Çolakoğlu ŞM, Genç Moralar D, Tok Çekmecelioğlu B, Hergünsel GO. Relationship of mortality with neutrophil/lymphocyte ratio, platelet/lymphocyte ratio, and mean platelet volume in patients undergoing acute abdominal surgery. Ulus Travma Acil Cerrahi Derg 2020;26:735-741

Address for correspondence: Döndü Genç Moralar, M.D.

SBÜ, Bakırköy Dr. Sadi Konuk Eğitim ve Araştırma Hastanesi, Anestezi ve Reanimasyon Kliniği, i̇stanbul, Turkey

Tel: +90 212 - $4147171 \quad$ E-mail: dondugencm@gmail.com

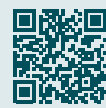

Ulus Travma Acil Cerrahi Derg 2020;26(5):735-74I DOI: 10.14744/tjtes.2020.8I783 Submitted: 21.05.2019 Accepted: 02.02.2020 Online: II.09.2020

Copyright 2020 Turkish Association of Trauma and Emergency Surgery 
Inflammation is a protective response to eliminate the body of the cause of cellular damage (e.g., microorganisms and toxins) and to remove the necrotic cells and tissues from the environment. ${ }^{[3]}$ While the causes of the acute abdomen may independently initiate the inflammatory cascade, stress that arises from the therapeutic, surgical intervention may also induce the inflammatory process. The systemic inflammatory response is associated with the altered white blood cell levels in the peripheral blood, particularly with neutrophilia, which occurs concomitantly with relative lymphocytopenia. ${ }^{[4]}$

The novel inflammation markers, such as neutrophil/lymphocyte ratio (NLR), platelet/lymphocyte ratio (PLR), and mean platelet volume (MPV), are under investigation for their predictive value for prognosis and mortality in critically ill patients. These markers have become popular in recent years and considered as a suitable predictor of the inflammatory events with other inflammatory predictors.

In the present study, we aimed to investigate the possible relationship between mortality and NLR, PLR, and MPV in patients who underwent acute abdominal surgery.

\section{MATERIALS AND METHODS}

This study included patients who were hospitalized in the intensive care unit (ICU) of Bakirkoy Dr. Sadi Konuk Training and Research Hospital and underwent acute abdominal surgery between 12.04.20I2 and 20.10.2017. The patient data were retrospectively analyzed. The study protocol was approved by the Clinical Trials Ethics Committee of Bakirkoy Dr. Sadi Konuk Training and Research Hospital (25.09.2017; No: 2017/287 2017-12-08). The study was conducted in accordance with the principles of the Declaration of Helsinki.

A total of 300 patients were screened in our database. Exclusion criteria were as follows: being under 18 years of age, being hospitalized shorter than 24 hours, receiving immunosuppressive therapy, having hematological malignancies, neutropenia and multiple short-time hospitalizations in the ICUs. As a result, a total of 249 patients who met the inclusion criteria were enrolled. The patient data were obtained from the PROBEL hospital information management system (Probel Computer Software Hardware Industry and Trade Inc., Izmir, Turkey) and the bedside recording system used in our ICU (Metavision; EMRall-QlinICU, Imdsoft/Metavision 5.46.38, USA). The 28-day mortality follow-up was done with the PROBEL and Mortality Notification System (OBS).

All patients were divided into two groups as survivors (Group I; $n=126$ ) and non-survivors (Group II; $n=123$ ). Parameters of the complete blood count (Sysmex XN3000 America, Inc ICU (Metavision; EMRall-QlinICU, Imdsoft/Metavision 5.46.38. 577 Aptakisic Road Lincolnshire, IL 60069, USA), biochemistry (Roche Cobas 8000 modular analyzer - Roche Diagnostics International Ltd. CH-6343 Rotkreuz, Switzer- land) and arterial blood gases (Siemens RAPIDLab I265AG Healthcare Sector Henkestrasse 12791052 Erlangen, Germany) were evaluated during the ICU stay. In addition, hemoglobin $(\mathrm{Hb})$, platelets, MPV, neutrophils, and lymphocytes were analyzed. The NLR and PLR values were calculated with the division of neutrophil count to the lymphocyte count and platelet count to the lymphocyte count, respectively. The albumin and lactate levels were also measured and the scores of APACHE II-IV, Sequential Organ Failure Assessment (SOFA) scores and Glasgow Coma Scale (GCS) were compared between the groups.

The primary aim of this study was to investigate the relationship between NLR, PLR and MPV in patients undergoing acute abdominal surgery admitted to our intensive care unit. The secondary aim of our study was to compare the scoring systems used to predict mortality (APACHE II-IV, SOFA, GCS) and the relationship between parameters such as lactate, albumin, hemoglobin and mortality.

\section{Statistical Analysis}

Statistical analysis was performed using the SPSS for Windows version 23.0 software package (IBM Corp., Armonk, NY, USA). Before this study, $95 \%$ power and $5 \%$ type I errors were predicted and the sample size was calculated as 180 patients, 90 patients in both groups. The descriptive data were expressed in mean, standard deviation (SD) for continuous variables and in number and percentage for categorical variables. The distribution of the variables was evaluated using the Kolmogorov-Smirnov test. The parametric and non-parametric tests were used to analyze normally and non-normally distributed variables, respectively. The Mann-Whitney $U$ test was used to compare non-normal distribution, while the Student's t-test was carried out to compare normal distribution between the groups. The relationship of the mortality with the blood parameters like NLR, PLR, and MPV in patients who underwent acute abdominal surgery logistic regression analysis was also carried out to examine the independent effect of each significant factor on the prediction of the mortality. The correlation analysis for continuous variables was performed using the Spearman's correlation coefficient. A p-value of <0.05 was considered statistically significant. According to the results, the power of the study was calculated as $70.9 \%$.

\section{RESULTS}

Of a total of 249 patients included in this study, I 32 (53\%) were males and 117 (47\%) were females. The mean age was $71.8 \pm 16.3$ in females and $67.7 \pm 16.8$ years in males (Table I).

A total of 126 patients $(50.6 \%)$ were referred to the clinic, and 123 patients (49.4\%) died. The mortality was $49.4 \%$ (Table I). The mean age was higher in Group II than Group I $(p=0.002)$. However, there was no significant correlation between sex and mortality $(p=0.416)($ Table I). 
Table I. Demographic characteristics of the patient groups

\begin{tabular}{ccccc}
\hline & Group I $(\mathbf{n = 1 2 6 )}$ & Group II $(\mathbf{n = 1 2 3 )}$ & Total & p \\
\hline Age $($ mean \pm SD $)$ & $66.2 \pm 18.2$ & $73.2 \pm 14.1$ & & $0.002^{*}$ \\
Sex, $n(\%)$ & & & \\
Female & $56(47.9)$ & $61(52.1)$ & $117(47)$ & $416^{* *}$ \\
Male & $70(53.0)$ & $62(47.0)$ & $132(53)$ \\
Total & $126(50.6)$ & $123(49.4)$ & $249(100)$ & \\
\hline
\end{tabular}

*Mann-Whitney $U$ test, $p<0.05$ was considered statistically significant. $* *$ Chi-square test, $p<0.05$ was considered statistically significant. SD Standard deviation.

Table 2. NLR, PLR, and MPV values of the patient groups

\begin{tabular}{lccr}
\hline & Group I & Group II & P \\
\cline { 2 - 3 } & Mean \pm SD & Mean \pm SD & \\
\hline Neutrophil/Lymphocyte ratio & $14.82 \pm 23.29$ & $15.13 \pm 15.56$ & 0.338 \\
Platelet/Lymphocyte ratio & $363.08 \pm 387.13$ & $370.11 \pm 634.17$ & 0.293 \\
Mean platelet volume & $8.50 \pm 1.76$ & $9.19 \pm 2.41$ & 0.004 \\
\hline *Mann-Whitney U test, $P<0.05$ was considered statistically significant. NLR: Neutrophil/lymphocyte ratio; PLR: Platelet/lymphocyte ratio; \\
MPV: Mean platelet volume; SD: Standard deviation.
\end{tabular}

Table 3. ROC analysis of the NLR, PLR, and MPV values

\begin{tabular}{|c|c|c|c|c|c|}
\hline & AUC & $\mathbf{p}$ & BTV & Sensitivity* & Specificity* \\
\hline NLR & 0.535 & 0.339 & 13.6136 & $41.46 \%$ & $70.63 \%$ \\
\hline PLR & 0.539 & 0.296 & 172.3404 & $36.59 \%$ & $78.57 \%$ \\
\hline MPV & 0.606 & 0.003 & 9.18 & $53.66 \%$ & $70.63 \%$ \\
\hline
\end{tabular}

There was no statistically significant difference in the NLR and PLR values between the groups. However, the MPV values were significantly higher in Group II $(p=0.004)(\mathrm{Ta}-$ ble 2). The diagnostic value of the NLR and PLR was not statistically significant (Table 3). The cut-off value of MPV was 9.18 and area under the curve (AUC) value was 0.606 and considered a significant predictor for mortality (Table 3) (Fig. I).

In the survivor group, we found a weak but statistically significantly negative correlation between the NLR and albumin, $\mathrm{Hb}$ and platelets $(r=-0.186,-0.218,-0.194 ; p<0.05)$ (Table 4). There was also a statistically significantly positive correlation between the PLR and platelets $(r=0,220 ; p<0.05)$ (Table 4). We also found a weak but statistically significantly negative correlation between the MPV and albumin and platelets $(r=-$ 0.182, -0.305; $p<0.05$ ) (Table 4).
There was a statistically significantly weak positive correlation between PLR and Platelet for the patients who died $(r=0.313$; $\mathrm{p}<0.05)$. There was a statistically significantly weak negative correlation between MPV and PLT $(r-0.205 ; p<0.05)$ (Table 4).

In Group II, APACHE II, APACHE IV, SOFA scores were significantly higher $(p<0.00 \mathrm{I}, \mathrm{p}<0.00 \mathrm{I}, \mathrm{p}<0.00 \mathrm{I})$ (Table 5).

There was not statistically significantly correlation between lactate levels, APACHE IV, SOFA, GCS score and NLR, PLR, MPV between the groups (Table 4).

\section{DISCUSSION}

In the present study, we investigated the relationship between mortality and NLR, PLR, and MPV in patients who underwent acute abdominal surgery. Our study results showed that NLR and PLR were not correlated with mortality, while MPV was 
Table 4. Correlation analysis

\begin{tabular}{|c|c|c|c|c|c|c|c|c|c|c|c|c|}
\hline & \multicolumn{6}{|c|}{ Group I } & \multicolumn{6}{|c|}{ Group II } \\
\hline & \multicolumn{2}{|c|}{ NLR } & \multicolumn{2}{|c|}{ PLR } & \multicolumn{2}{|c|}{ MPV } & \multicolumn{2}{|c|}{ NLR } & \multicolumn{2}{|c|}{ PLR } & \multicolumn{2}{|c|}{ MPV } \\
\hline & $\mathbf{r}$ & $\mathbf{p}$ & $\mathbf{r}$ & $\mathbf{p}$ & $\mathbf{r}$ & $\mathbf{p}$ & $\mathbf{r}$ & $\mathbf{p}$ & $\mathbf{r}$ & $\mathbf{p}$ & $\mathbf{r}$ & $\mathbf{p}$ \\
\hline Age & 0.079 & 0.380 & 0.182 & 0.041 & 0.035 & 0.701 & 0.083 & 0.361 & 0.005 & 0.960 & 0.039 & 0.671 \\
\hline APACHE-II score & -0.023 & 0.798 & 0.013 & 0.885 & 0.060 & 0.502 & -0.047 & 0.605 & -0.077 & 0.400 & -0.022 & 0.808 \\
\hline APACHE-IV score & -0.023 & 0.796 & -0.011 & 0.904 & -0.001 & 0.988 & 0.113 & 0.214 & -0.082 & 0.368 & 0.130 & 0.152 \\
\hline SOFA score & -0.092 & 0.307 & -0.004 & 0.968 & 0.030 & 0.741 & 0.049 & 0.590 & -0.145 & 0.111 & 0.120 & 0.185 \\
\hline GCS score & -0.044 & 0.625 & -0.170 & 0.057 & 0.145 & 0.106 & 0.145 & 0.110 & 0.102 & 0.263 & -0.021 & 0.817 \\
\hline Lactate & 0.006 & 0.946 & -0.039 & 0.669 & 0.168 & 0.060 & -0.069 & 0.446 & -0.074 & 0.416 & 0.127 & 0.163 \\
\hline Albumin & -0.186 & 0.038 & -0.133 & 0.139 & -0.182 & 0.041 & $-0.04 I$ & 0.656 & 0.029 & 0.752 & -0.031 & 0.733 \\
\hline $\mathrm{Hb}$ & -0.218 & 0.015 & -0.068 & 0.449 & -0.061 & 0.495 & -0.007 & 0.938 & 0.064 & 0.480 & 0.147 & 0.105 \\
\hline Platelets & -0.194 & 0.030 & 0.220 & 0.013 & -0.305 & 0.001 & -0.040 & 0.659 & 0.313 & $<0.001$ & -0.205 & 0.023 \\
\hline
\end{tabular}

NLR: Neutrophi//lymphocyte ratio; PLR: Platelet/lymphocyte ratio; MPV: Mean platelet volume; ASA: American Society of Anesthesiologists; APACHE: Acute Physiology and Chronic Health Evaluation; SOFA: Sequential Organ Failure Assessment; GCS: Glasgow Coma Scale; Hb: Hemoglobin.

Table 5. Clinical scoring values by groups

\begin{tabular}{|c|c|c|c|}
\hline & Group I & Group I & $\mathbf{p}$ \\
\hline & Mean $\pm S D$ & Mean $\pm S D$ & \\
\hline APACHE-II score & $19.8 \pm 7.8$ & $26.6 \pm 7.9$ & $<0.001^{*}$ \\
\hline APACHE-IV score & $90.5 \pm 35.9$ & $125.7 \pm 39.6$ & $<0.001^{*}$ \\
\hline SOFA score & $6.5 \pm 3.9$ & $10.6 \pm 4.4$ & $<0.001^{*}$ \\
\hline
\end{tabular}

statistically significantly correlated with mortality. In clinical practice, various blood parameters have been used to predict prognosis and mortality in the intensive care setting.

The NLR is the proportion of the neutrophil count, which reflects the severity of the inflammation, to the lymphocyte count, which is altered depending on the physiological stress. There are several studies in the literature using NLR as a marker in certain acute abdominal events, including mesenteric ischemia, peptic ulcer perforation, and acute cholecystitis, as a marker of lymph node metastasis in certain types of cancer and investigating its value in vascular events, such as aorta dissection and acute coronary syndrome, in rheumatic diseases, such as rheumatoid arthritis and ankylosing spondylitis, in the exacerbation of chronic obstructive lung disease, after acute tonsillitis and several infections such as deep neck infection..$^{[5-10]}$

In our study, we found no significant difference between the groups concerning the NLR values (for survivors:

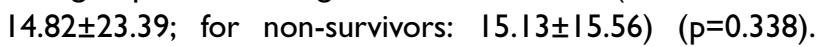
Although there are more than one threshold values in the literature, the AUC value was 0.535 in our ROC analysis of the NLR. However, we were unable to identify any significant threshold value in our study.

Forget et al. ${ }^{[I]}$ conducted a study to identify the lower and upper limits of NLR in healthy individuals and included participants between the ages of 12 and 66 years, who did not have any active disease, including malignancy and infectious diseases. The authors reported that the normal values of NLR were between 0.78 and 3.53 .

In another study conducted by Augène et al. ${ }^{[12]}$ with patients with acute mesenteric ischemia, no statistically significant difference was found, even though patients with higher NLR tend to have higher mortality.

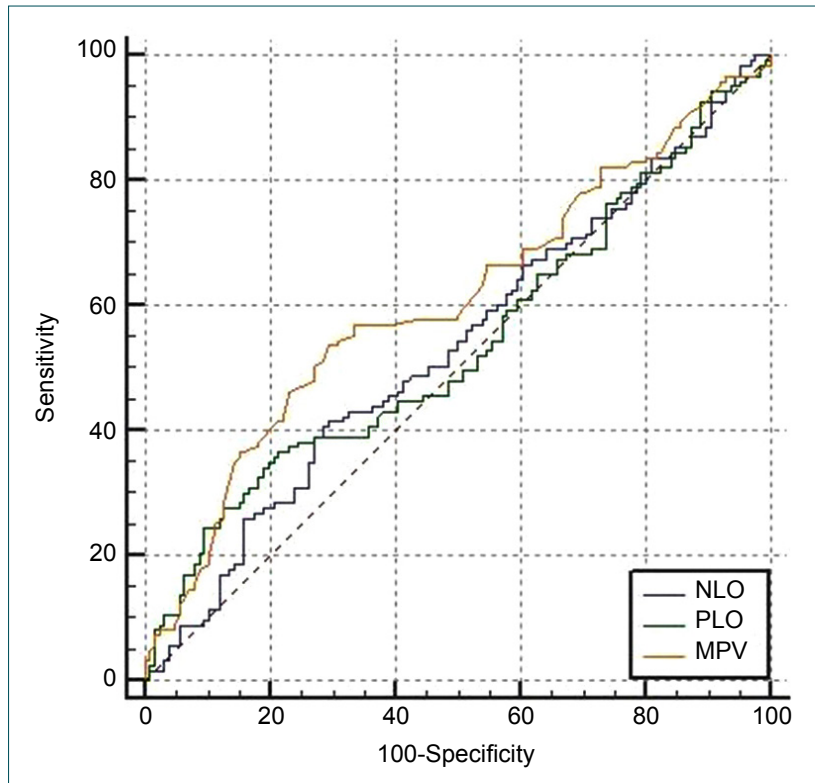

Figure 1. ROC analysis of NLR, PLR, and MPV values. 
Mean platelet volume is an accurate measure of platelet size and reflects the reactivity of platelets. It is considered that it plays a key role in the activation of the thrombosis and platelets with the predisposition in the pathophysiology of inflammation. ${ }^{[13]}$

Several studies have shown that changes in MPV have been observed during infection, sepsis, coronary artery disease, cerebrovascular diseases, arterial and venous thrombosis, and chronic inflammatory disorders. ${ }^{[14,15]}$

In Beyazit et al.'s ${ }^{[16]}$ study, the MPV values were prominently decreased in patients with acute pancreatitis, compared to the control group. In the aforementioned study, decreased MPV values were found to be associated with poor prognosis without any advantage over other inflammatory markers in predicting prognosis. However, in another study, the MPV values significantly increased in patients with complicated acute pancreatitis. ${ }^{[17]}$

Kim et al. ${ }^{[18]}$ showed that platelet count and MPV were higher in patients who died of severe sepsis and/or septic shock than those who survived the first 72 hours after admission. In a similar sepsis study, MPV was found to be significantly different between those who died and survived sepsis. ${ }^{[15]}$

In our study, MPV values were higher in Group II than Group

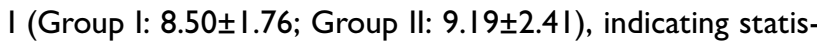
tical significance for mortality $(p=0.004)$. The best threshold value of MPV for mortality was found to be 9.18 , and the sensitivity, specificity, and AUC values were $53.66 \%, 70.63 \%$, and 0.606 , respectively.

In the literature, the relationship between increased MPV and mortality was investigated in many disease groups and ICU patients. Although there is a significant relationship between comorbid diseases and MPV concerning mortality, there are studies showing that MPV value in intensive care patients is not associated with predicting mortality. In our study, we found a significant relationship between increased MPV and mortality.

The platelet count is another hematological marker of inflammation, which has a predictive role in survival. It has been shown that MPV is an independent risk factor for poor survival in patients with pancreatic or colorectal cancer. ${ }^{[19,20]}$

In another study involving 34 patients with acute mesenteric ischemia, it was found that PLR was significantly higher in patients who died compared to survivors (373.8-288.5, $\mathrm{p}=0.045) \cdot{ }^{[21]}$

Duman et al. ${ }^{[22]}$ conducted a study on sepsis patients; however, they found no significant difference in the PLR values between the groups with and without mortality $(p=0.336)$. In our study, similar to the study of Duman et al., ${ }^{[22]}$ we found no statistically significant difference in the PLR values between the groups (Group I: $363.08 \pm 387.13$; Group II: 370.I I $\pm 634.17 ; p=0.293$ ). The AUC value was 0.539 and a significant threshold value was unable to be identified. We also found that NLR and PLR could not be used as a predictor of mortality, although MPV could be used for this purpose.

NLR and PLR are systemic inflammatory markers that may be affected by the comorbidities of patients. ${ }^{[23,24]}$ In our study, we found that NLR and PLR were not usable in predicting mortality.

In our study, blood samples were taken at the time of admission to the intensive care unit, not at the time of admission to the emergency department. We think that the follow-up, including the patient's pre-operation, will be more meaningful. Furthermore, this study will be performed on more patients and this will increase the power of this study.

In the ICUs, where the mortality is relatively high, albumin and $\mathrm{Hb}$ values are correlated with mortality. In another study, Jansen et al. ${ }^{[25]}$ evaluated patients treated in the ICUs due to sepsis, hemorrhagic shock, and other conditions leading to low oxygen transportation and measured the arterial lactate levels at 12 and $24 \mathrm{~h}$. A decline in the lactate levels at $24 \mathrm{~h}$ reduced mortality in the patients with sepsis. Furthermore, albumin levels can be used to predict the mortality risk.

In our study, we found that the APACHE II-IV and SOFA scores were useful in the prediction of the mortality, which is consistent with the literature. All three scores were higher in the non-survivor patients, compared to the survivors. In the present study, the results of the scoring systems are consistent with the literature in patients who underwent acute abdominal surgery.

Brinkman et al. ${ }^{[26]}$ suggested that the APACHE IV was more reliable than APACHE II, considering the prediction of the mortality in the ICUs in the Netherlands. In addition, there are several studies using SOFA scores for the prediction of mortality. One of these studies, which is also consistent with our study findings, was conducted by Hwang SY et al. ${ }^{[2]}$ The authors suggested that combined scoring systems could be used in the trauma patients. The first-day SOFA scores were significantly higher in the non-survivors, indicating that it may have a predictive value for the prolonged hospitalization durations. Nonetheless, there are some limitations to this study. First, the causes of the deaths were not recorded and classified. Second, our study has a single-center design with a small sample size. Third, the parameters were measured in the first blood samples taken after surgery, and a comparative study with serial measurements was unable to be carried out. Therefore, we believe that further large-scale, multi-center studies with serial measurements are needed to confirm our findings. 


\section{Conclusion}

In conclusion, our study results demonstrated that NLR and PLR were not associated with mortality. On the other hand, MPV values were significantly higher in the non-survivors following acute abdominal surgery. Further studies are needed to gain a better understanding of the predictive role of these markers in this patient population.

Ethics Committee Approval: Approved by the local ethics committee.

Peer-review: Internally peer-reviewed.

Authorship Contributions: Concept: Ş.M.Ç., D.G.M., B.T.Ç., G.O.H.; Design: Ş.M.Ç., D.G.M.; Supervision: D.G.M., G.O.H.; Fundings: Ş.M.Ç.; Materials: Ş.M.Ç., B.T.Ç.; Data: Ş.M.Ç., B.T.Ç.; Analysis: Ş.M.Ç., D.G.M., G.O.H.; Literature search: Ş.M.Ç., D.G.M., B.T.Ç., G.O.H.; Writing: Ş.M.Ç., D.G.M.; Critical revision: D.G.M.

\section{Conflict of Interest: None declared.}

Financial Disclosure: The authors declared that this study has received no financial support.

\section{REFERENCES}

1. Turan M, Şen M, Koyuncu A, Aydın C, Karadayı K, Canbay E. The Acute Abdomen with Recent Advances. Cumhuryet University J Med School 2002;24:45-52.

2. Quach S, Hennessy DA, Faris P, Fong A, Quan H, Doig C. A comparison between the APACHE II and Charlson Index Score for predicting hospital mortality in critically ill patients. BMC Health Serv Res 2009;30:9:129 [CrossRef]

3. Güç D. Inflammation. J Curr Med 1998;3:126-4.

4. Zahorec R. Ratio of neutrophil to lymphocyte counts--rapid and simple parameter of systemic inflammation and stress in critically ill. Bratisl Lek Listy 2001;102:5-14.

5. Aktimur R, Cetinkunar S, Yildirim K, Aktimur SH, Ugurlucan M, Ozlem N. Neutrophil-to-lymphocyte ratio as a diagnostic biomarker for the diagnosis of acute mesenteric ischemia. Eur J Trauma Emerg Surg 2016;42:363-8 [CrossRef]

6. Jung J, Park SY, Park SJ, Park J. Prognostic value of the neutrophil-to-lymphocyte ratio for overall and disease-free survival in patients with surgically treated esophageal squamous cell carcinoma. TumourBiol 2016;37:7149-54 [CrossRef]

7. Dirican N, Karakaya YA, Gunes S, Daloglu FT, Dirican A. Association of intra-tumoral tumour-infiltrating lymphocytes and neutrophil-to-lymphocyte ratio is an independent prognostic factor in non-small cell lung cancer. Clin Respir J 2017;11:789-96 [CrossRef]

8. Zhou D, Wan Z, Fan Y, Zhou J, Yuan Z. A combination of the neutrophil-to-lymphocyte ratio and the GRACE risk score better predicts PCI outcomes in Chinese Han patients with acute coronary syndrome. Anatol J Cardiol 2015;15:995-1001 [CrossRef]

9. Tekeoğlu İ, Gürol G, Harman H, Karakeçe E, Çiftçi İH. Overlooked hematological markers of disease activity in rheumatoid arthritis. Int J Rheum Dis 2016;19:1078-82. [CrossRef]

10. Sevim Y, Namdaroglu OB, Akpınar MY, Ertem AG. The diagnostic value of neutrophil lymphocyte ratio in acute appendicitis. Sakaryamj 2014;4:78-81 [CrossRef]
11. Forget P, Khalifa C, Defour JP, Latinne D, Van Pel MC, De Kock M. What is the normal value of the neutrophil-to-lymphocyte ratio?. BMC Res Notes 2017;10:12. [CrossRef]

12. Augène E, Lareyre F, Chikande J, Guidi L, Ballaith A, Bossert JN, Pelletier Y, Caradu C, Hassen-Khodja R, Raffort J. Platelet to lymphocyte ratio as a predictive factor of 30-day mortality in patients with acute mesenteric ischemia. PLoS One 2019;14:e0219763. [CrossRef]

13. Paraskevas F, Greer JP, Rodgers GM. Variations of leucocytes in disease. In: Wintrobe's Clinical Hematology. Lee GR, Foerster J, Lukens J, editors. 10th edition. Baltimore: Lippincott Williams and Wilkins;1999.p.1836-61.

14. Chu SG, Becker RC, Berger PB, Bhatt DL, Eikelboom JW, Konkle B, et al. Mean platelet volume as a predictor of cardiovascular risk: a systematic review and meta-analysis. J Thromb Haemost 2010;8:148-5ф. [CrossRef]

15. Azab B, Torbey E, Singh J, Akerman M, Khoueiry G, McGinn JT, et al. Mean platelet volume/platelet count ratio as a predictor of longterm mortality after non-ST-elevation myocardial infarction. Platelets 2011;22:557-66 [CrossRef]

16. Beyazit Y, Sayilir A, Torun S, Suvak B, Yesil Y, Purnak T, et al. Mean platelet volume as an indicator of disease severity in patients with acute pancreatitis. Clin Res Hepatol Gastroenterol 2012;36:162-8 [CrossRef]

17. Akbal E, Demirci S, Koçak E, Köklü S, Başar O, Tuna Y. Alterations of platelet function and coagulation parameters during acute pancreatitis. Blood Coagul Fibrinolysis 2013;24:243-6. [CrossRef]

18. Kim CH, Kim SJ, Lee MJ, Kwon YE, Kim YL, Park KS, et al. An increase in mean platelet volume from baseline is associated with mortality in patients with severe sepsis or septic shock. PLoS One 2015;10:e0119437.

19. Smith RA, Bosonnet L, Raraty M, Sutton R, Neoptolemos JP, Campbell $F$, et al. Preoperative platelet-lymphocyte ratio is an independent significant prognostic marker in resected pancreatic ductal adenocarcinoma. Am J Surg 2009;197:466-72 [CrossRef]

20. Kwon HC, Kim SH, Oh SY, Lee S, Lee JH, Choi HJ, et al. Clinical significance of preoperative neutrophil-lymphocyte versus platelet-lymphocyte ratio in patients with operable colorectal cancer. Biomarkers 2012;17:216-22 [CrossRef]

21. Yılmaz EM, Cart1 EB. Prognostic factors in acute mesenteric ischemia and evaluation with Mannheim Peritonitis Index and platelet-to-lymphocyte ratio. Ulus Travma Acil Cerrahi Derg 2017;23:301- . [CrossRef]

22. Duman A, Akoz A, Kapci M, Ture M, Orun S, Karaman K, Turkdogan KA. Prognostic value of neglected biomarker in sepsis patients with the old and new criteria: predictive role of lactate dehydrogenase. Am J Emerg Med 2016;34:2167-71 [CrossRef]

23. Lin BD, Hottenga JJ, Abdellaoui A, Dolan CV, de Geus EJC, Kluft C, et al. Causes of variation in the neutrophil-lymphocyte and platelet-lymphocyte ratios: a twin-family study Biomark Med 2016;10:1061-72.

24. Qin B, Ma N, Tang Q, Wei T, Yang M, Fu H, et al. Neutrophil to lymphocyte ratio (NLR) and platelet to lymphocyte ratio (PLR) were useful markers in assessment of inflammatory response and disease activity in SLE patients. Mod Rheumatol 2016;26:372- [ [CrossRef]

25. Jansen TC, van Bommel J, Mulder PG, Lima AP, van der Hoven B, et al. Prognostic value of blood lactate levels: does the clinical diagnosis at admission matter? J Trauma 2009;66:377-8 5 . [CrossRef]

26. Brinkman S, Bakhshi-Raiez F, Abu-Hanna A, de Jonge E, Bosman RJ, Peelen L, et al. External validation of Acute Physiology and Chronic Health Evaluation IV in Dutch intensive care units and comparison with Acute Physiology and Chronic Health Evaluation II and Simplified Acute Physiology Score II. J Crit Care 2011;26:105.e11-105. e1.05E18 [CrossRef]

27. Hwang SY, Lee JH, Lee YH, Hong CK, Sung AJ, Choi YC. Compari- 
son of the Sequential Organ Failure Assessment, Acute Physiology and Chronic Health Evaluation II scoring system, and Trauma and Injury
Severity Score method for predicting the outcomes of intensive care unit trauma patients. Am J Emerg Med 2012;30:749-53. [CrossRef]

\section{ORIJIINAL ÇALIŞMA - ÖZET}

\section{Akut karın cerrahisi geçiren hastalarda, nötrofil-lenfosit oranı, trombosit-lenfosit oranı ve ortalama trombosit hacminin mortalite ile ilişkisi \\ Dr. Şükran Merve Çolakoğlu, ${ }^{1}$ Dr. Döndü Genç Moralar, ${ }^{2}$ Dr. Büşra Tok Çekmecelioğlu, ${ }^{3}$ Dr. Gülsüm Oya Hergünsel ${ }^{2}$}

'Sağlık Bilimleri Üniversitesi, Gaziosmanpaşa Taksim Eğitim ve Araştırma Hastanesi, Anestezi ve Reanimasyon Kliniği, İstanbul 2Sağlık Bilimleri Üniversitesi, Bakırköy Dr. Sadi Konuk Eğitim ve Araştırma Hastanesi, Anestezi ve Reanimasyon Kliniği, İstanbul ${ }^{3}$ Sağlık Bilimleri Üniversitesi, Sultan Abdulhamid Han Eğitim ve Araştırma Hastanesi, Anestezi ve Reanimasyon Kliniği, İstanbul

AMAÇ: Akut karın cerrahisi sonrası yüksek oranda mortalite ve morbidite görülmekte, postoperatif dönemde sıklıkla yoğun bakım ihtiyacı olmaktadır. Yoğun bakım ünitelerinde, prognoz ve mortaliteyi belirlemek amacıyla çeşitli skorlama sistemleri kullanılmakta ancak mortalite ve prognozu öngörmede yeterli olmamaktadır. Bu amaçla kolay uygulanabilir, etkin yöntemler araştııımaktadır. Biz bu çalısmada, akut karın cerrahisi geçiren hastalarda nötrofil-lenfosit oranı (NLO), trombosit-lenfosit oranı (TLO) ve ortalama trombosit hacmi (OTH) gibi kan parametrelerinin mortalite ile ilişkisini araştırmayı amaçladık.

GEREÇ VE YÖNTEM: Bu çalışmaya, akut karın ameliyatı geçiren 249 hasta alındı. Hastalar sağ kalan $(n=126)$ ve ölenler $(n=123)$ olarak iki gruba ayrıldı. Hasta verileri retrospektif olarak incelendi. NLO, TLO ve OTH değerleri gruplar arasında karşılaştırı) nik Sağıık Değerlendirmesi II-IV skorları (APACHEII-IV), Sıralı Organ Yetmezliği Değerlendirme skorları (SOFA), Glasgow Koma Skalası gibi veriler değerlendirildi.

BULGULAR: Çalışmamızda mortalite oranı \%49.4 idi. NLO ve TLO değerlerinde gruplar arasında istatistiksel olarak anlamlı fark yoktu. Ancak, OTH ölenler grubunda anlamlı olarak yüksek bulundu $(p<0.004)$.

TARTIŞMA: Çalışma sonuçlarımız akut karın cerrahisi sonrası hayatını kaybedenlerde OTH değerlerinin anlamlı derecede yüksek olduğunu ve NLO ve TLO'nın mortalite ile ilişkili olmadığını göstermiştir.

Anahtar sözcükler: Akut karın; bakım ünitesi; mortalite, nötrofil lenfosit oranı; ortalama trombosit hacmi; trombosit lenfosit oranı.

Ulus Travma Acil Cerrahi Derg 2020;26(5):735-741 doi: 10.14744/tjtes.2020.8I783 